\title{
Characterization of Okra Convective Drying, Influence of Maturity
}

\author{
Ouoba Kondia Honoré1,2, Zougmoré François' ${ }^{1}$, Sam Raguilignaba1, \\ Toguyeni Aboubacar ${ }^{3}$, Desmorieux Hélène ${ }^{2}$ \\ ${ }^{1}$ Laboratoire des Matériaux et Environnement (LAME), Unité de Formation et de Recherche en Sciences \\ Exactes et Appliquée (UFR/SEA), Université de Ouagadougou, Ouagadougou, Burkina Faso \\ ${ }^{2}$ Laboratoire d'Automatisme et de Génie des Procédés (LAGEP), UCBL1-CNRS UMR 5007-CPE Lyon, Bât.308G, \\ 43 bd du 11 Nov. 1918 Villeurbanne, Université Claude Bernard Lyon 1, 69622, Lyon, France \\ ${ }^{3}$ Institut de Développement Rural, Université Polytechnique de Bobo, Bobo-Dioulasso, Burkina Faso \\ Email: ouobakahonore@yahoo.fr
}

Received 10 December 2013; revised 10 January 2014; accepted 17 January 2014

Copyright (C) 2014 by authors and Scientific Research Publishing Inc.

This work is licensed under the Creative Commons Attribution International License (CC BY). http://creativecommons.org/licenses/by/4.0/

(c) (i) Open Access

\begin{abstract}
An experimental study for the drying kinetics of whole okra was carried out. In the study, different ages were considered by taking into account influence of okra maturity on its convective drying. The 2D moisture evolution inside the product and its maturity were evaluated by fitting experimental data versus drying time. The water effective diffusion coefficient of okra at different maturity states was gotten by the experimental model using Fick's second law. A parametric study was carried out in the ranging of okra age from 2 to 7 days at $60^{\circ} \mathrm{C}$, both fruits gathered on the same plant to avoid divergences due to okra varieties that can induce difference on physical structure and the chemical composition. It was found from the experimental results that okra maturity has important influence on its behaviour during convective drying. At 2, 3, 4, 5 and 7 days old, the drying effective time was respectively $780,1000,1155,850$ and $750 \mathrm{~min}$. Effective diffusivity of the okra in this order of age was $1.38 \times 10^{-10}, 6.09 \times 10^{-11}, 1.23 \times 10^{-11}, 8.98 \times 10^{-11}$, and $1.05 \times 10^{-10} \mathrm{~m}^{2} / \mathrm{s}$ in the present study, while the average initial moisture content was respectively $12.27,9.00,7.53,5.97$ and $4.92 \mathrm{Kg}_{\mathrm{w}} / \mathrm{Kg}_{\mathrm{dm}}$.
\end{abstract}

\section{Keywords}

Convective Drying; Okra; Effective Diffusivity; Maturity; Initial Moisture Content

\section{Introduction}

Okra is one of the most significant fruit vegetables grown throughout the tropics and warmer parts of the tem- 
perate climatic zone [1]. It is well dried in tropical zone and very appreciated in nutrition, due in part to its content in nutritive elements [2]. Okra seeds have content in oil in order of $15 \%-19 \%$ and its proteins are in good quality [3]. Also, okra has polysaccharide content giving a strong viscous and sticky solution appearance [4]. Moreover, it has medicinal use to fight against some cardiovascular and dental diseases and decreases gastric irritations. It is also used as diuretic agent. These properties of okra are due to its contain in oligomerics catechins, derived flavonol (respectively $2.5 \mathrm{mg} / \mathrm{g}$ and $3.4 \mathrm{mg} / \mathrm{g}$ per seeds) and polyphenol with hydroxycinnamic and quercetins (0.2 and $0.3 \mathrm{mg} / \mathrm{g}$ of its skins) [5]. Physically, okra has cylindrical shape and conical extremity, supported by a peduncle. It has a complex inside structure. The cut, from the outside to inward, shows a thick skin, then a spongy material in the center. Between both, there are alveoli, creating cavities which accommodate spherical seeds. These three materials have different structures [6].

The production in 2004 was more than 4.5 millions of tons in more than 33 countries with India in top (3.5 million tons). In West Africa, Nigeria is the largest producer (1,039,000 t) followed by Ivory Coast, Ghana and others [7].

To preserve the high produced quantity, the producers, generally women in Africa, proceed to its drying. The product is then cut in various sizes [8] and displayed directly in the sun or, more rarely, in solar-dryers. Most of dryings are achieved without control of the relative humidity, air temperature or drying air flow, above all, without distinction of age. The dried product has often doubtful and inhomogeneous quality, losing the initial organoleptic quality. However, it is not advisable, for mastering okra drying phenomena and its mechanical behavior, to study solely the whole okra behavior, without examining the effect of okra age on its convective drying. So, we can obtain an acceptable final quality, which takes into account its appreciation in the food domain and its therapeutic virtues.

In this work, we characterized the convective drying of the whole okra with regard to the influence of maturety on okra convective drying. Through the drying curves as well as effective diffusivity of the whole product and initial water content, we point up the complex character of okra and its age effect during convective drying. A parametric study was carried out in the range of okra old from 2 to 7 days at $60^{\circ} \mathrm{C}$, both fruits gathered on the same plant to avoid divergences due to okra variety, particular physical structure and the chemical composition [9].

\section{Materials and Method}

\subsection{Experimental Material and Samples Preparation}

Freshly okra samples were obtained from a farm in Bobo-Dioulasso, which is located in the west of Burkina Faso, in September 2012. The samples for each experiment were collected on the same tree, to avoid divergences due to variety that can induce difference into physical structure and the chemical composition [9].

As soon as the plant of the okra is selected, it is marked. In the appearance of a flower, we mark and follow its advancement. When the flower gives a fruit, this day is noted 0 . The first day will correspond to the first anniversary of the fruit. Let us note that in the first day the fruit is so young that we do not collect it at first. At the second day, the fruit reaches almost its final size (for a good fertile and rather wet soil). Let us remind that the okra is appreciated in food at 2 - 5 days beyond of which, the fruit increases its content in fiber, hardens and thus unfit for consumption. The okras were washed, and then were transported to Polytechnic University of BoboDioulasso situated about $30 \mathrm{~min}$ from the farm where okras were obtained. The initial water content, determined by drying in an oven dryer at $105^{\circ} \mathrm{C}$ for $4 \mathrm{~h}$ [10], performed in triplicate, was found to be $8.47 \% \pm 2.067 \%$ in dry basis with initial weigh of $11.22 \pm 2.55 \mathrm{~g}$.

Figure 1 shows the constitution of the okra, from the outside inward. A thick skin wraps seeds fixed to a spongy material constituting the central axis of the okra.

Figure 2 shows the existing differences between the various states of maturity of the okra. Young fruits which are generally edible are soft and breakable. Advanced in age fruits increase their content in fibers and become flexible.

\subsection{Drying Equipment}

Drying kinetics of okra samples were established using a natural convection oven-dryer (WTF BINDER). The average temperature was regulated at $60^{\circ} \mathrm{C}$. For drying, the samples were placed in the oven-dryer initially re- 


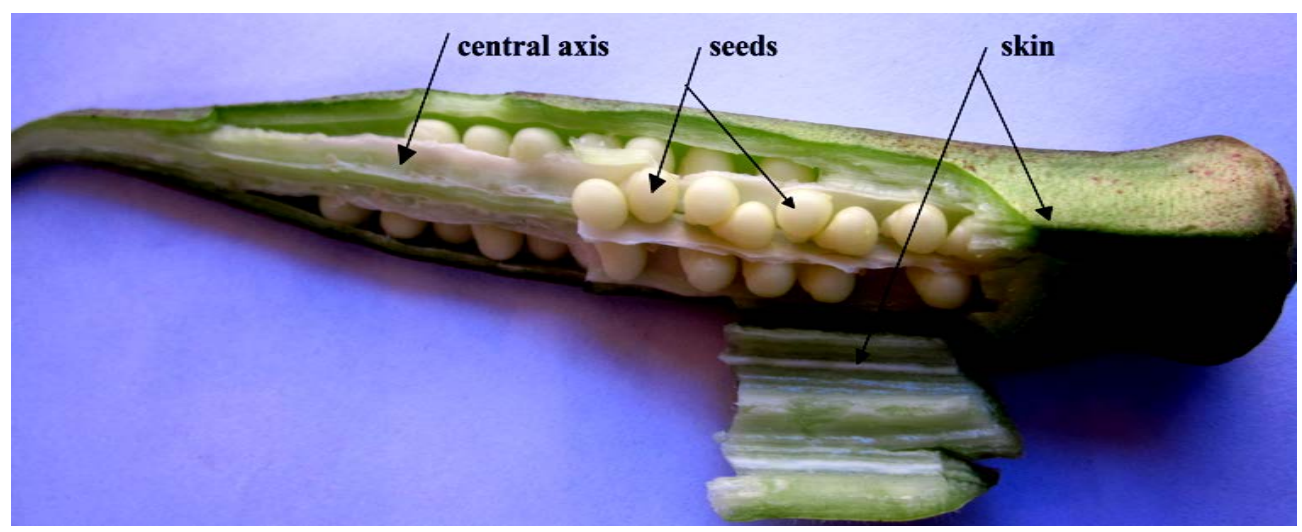

Figure 1. Okra physical external and internal constitution.

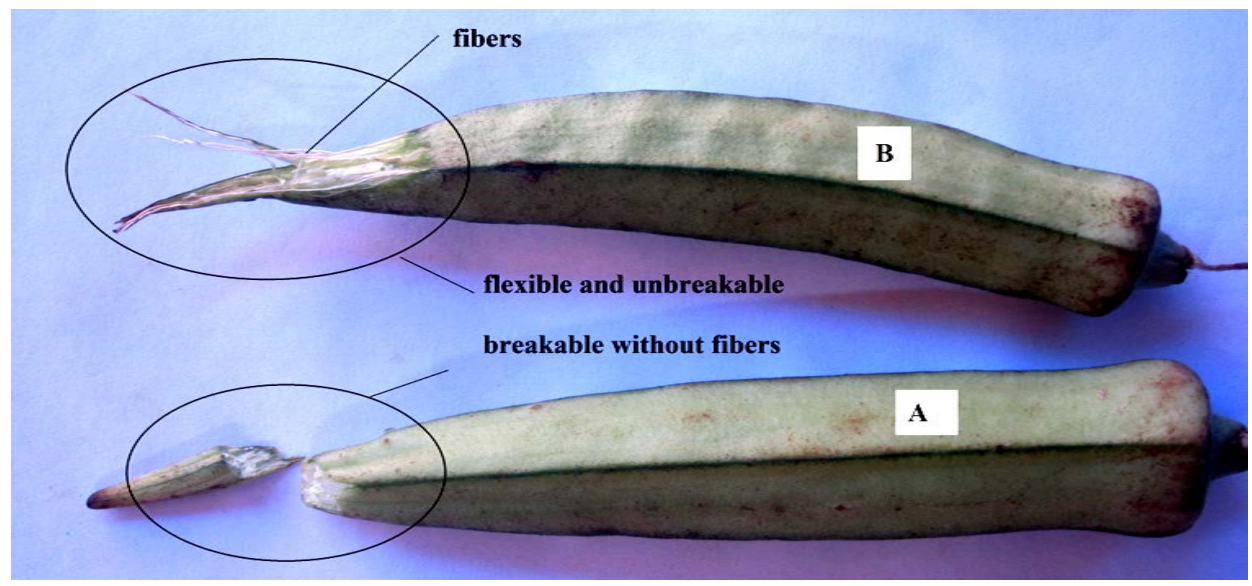

Figure 2. Different states of maturity: (A) 2 - 6 days old, no fiber and breakable at the extremity; (B) 5 - 8 days old, high content in fibers, unbreakable at the extremity.

gulated to the drying temperature. During drying, the samples weight was regularly measured with a balance (Master Pro SARTORIUS, 0.001 g precision, France). These measurements were done every 10 - 15 min during the first $200 \mathrm{~min}$. Then, because of the drying rate decrease, measurements were taken every $20-25$ min until 300 min drying and finally every 30 - 35 min until the last stage of drying. At the end of each experiment, the dry mass $m_{s}$ of the product was obtained by drying the sample in the oven dryer at $105^{\circ} \mathrm{C}$ for $24 \mathrm{~h} \mathrm{[10]}$ (AOAC, 1990). From the initial mass $m_{0}$ and dry mass $m_{s}$, the initial water content of each sample was determined by the following equation:

$$
X_{0}=\frac{m_{w}}{m_{s}}=\frac{m_{o}-m_{s}}{m_{s}} .
$$

where $m_{w}$ is the mass of water inside the product.

\subsection{Okra Convective Drying Characterization}

The shrinkage curves were established by measuring the mass $m(t)$ of okra at any time. The mass value decreases in proportion as drying time increase. At the end, the product keeps its mass constant then the dry mass $m_{s}$ is determined.

From mass loss curves and dry mass, the water content at each instant of drying and the drying kinetics were determined.

$$
X(t)=\frac{m(t)-m_{s}}{m_{s}} .
$$


Drying kinetics of okra samples were established by fitting $X(t)$ versus drying time.

\subsection{Calculation of Moisture Difusivity}

The moisture ratio $(M R)$ of samples was calculated using by the following equation:

$$
M R=\frac{X_{t}-X_{e q}}{X_{o}-X_{e q}} .
$$

where, in $\left(\mathrm{kg}_{\mathrm{w}} / \mathrm{kg}_{\mathrm{dm}}\right), X_{\mathrm{t}}$ is the moisture content at any time, $X_{0}$ is the initial moisture content and $X_{e}$ is the equilibrium moisture content.

The experimental drying data for the determination of diffusivity coefficient were interpreted by using Fick's second diffusion model. The solution of Fick's second law for diffusion out of cylindrical form may be used to fit the experimental drying data [11]:

$$
M R=\frac{X_{t}-X_{e q}}{X_{o}-X_{e q}}=\frac{4}{\beta^{2}} \exp \left(-\frac{\beta^{2} D_{e f f} t}{r_{c}^{2}}\right) .
$$

Equation (4) assumes that the effective diffusivity $\left(D_{\text {eff }}\right)$ is constant, shrinkage of the sample is negligible for long drying times and okra was considered having cylindrical form. Several researchers demonstrated that Equation (4) could be further simplified to a straight-line equation as [12]-[14]:

$$
\ln (M R)=\ln \left(\frac{4}{\beta^{2}}\right)-\left(\frac{\beta^{2} D_{e f f}}{r_{c}^{2}}\right) \cdot t .
$$

The effective diffusivities were determined using the method of slopes. Effective diffusivities are typically determined by plotting experimental drying data in terms of $\ln (M R)$ versus time. From Equation (5), a plot of $\ln (M R)$ versus time gives a straight line with a slope $k$ containing $D_{\text {eff: }}$ :

$$
k=\frac{\beta^{2} D_{e f f}}{r_{c}^{2}}
$$

\section{Results and Discussion}

The drying experiments were carried out using the 2, 3, 4, 5 and 7 days old of okra. The samples presented average initial moisture content from $12.27 \mathrm{Kg}_{\mathrm{w}} / \mathrm{Kg}_{\mathrm{dm}}$ to $4.92 \mathrm{Kg}_{\mathrm{w}} / \mathrm{Kg}_{\mathrm{dm}}$ according to their age. The air drying temperature was settled at $60^{\circ} \mathrm{C}$. All the tests were repeated at least twice for repeatability.

\subsection{Water Content Change with Maturity Process}

The effect of the age of okra fruit on the variation of the global moisture content of the whole okra during the drying process was evaluated. Figure 3 presents the initial moisture content for the different maturity degree. It can be seen from the results that the initial moisture content values decreased as the maturity degree was growing up. Advanced in age, the fruit becomes more and more steady which decreases the proportion of water in the sample. The experiment were carried out on whole okras gathered on two different plants noted "Plant 1" and "Plant 2". All of them gave similar results. The younger okra generally had the highest initial water content while the older okra had the least initial water content. Whole okra at 2, 3, 4, 5 and 7 days old has respectively $12.27,9.00,7.53,5.97$ and $4.92 \mathrm{Kg}_{\mathrm{w}} / \mathrm{Kg}_{\mathrm{dm}}$ of initial water contain. This suggests that at the first days, okra is affluent in water while solid matter becomes more and more abundant when age increase

\subsection{Influence of Okra Maturity on Its Drying Curves}

Figure 4 presents the drying curves for samples at $60^{\circ} \mathrm{C}$ with maturity (days old) of 2, 3, 4, 5 and 7 days old both from the same plant to reduce variety or other genetic aspect influences on the result. Each drying kinetics experiment was carried out at least twice to check the reproducibility of the drying curves. All the drying in case of okra takes place in the falling rate period. This shows that diffusion is the dominant physical mechanism gov- 


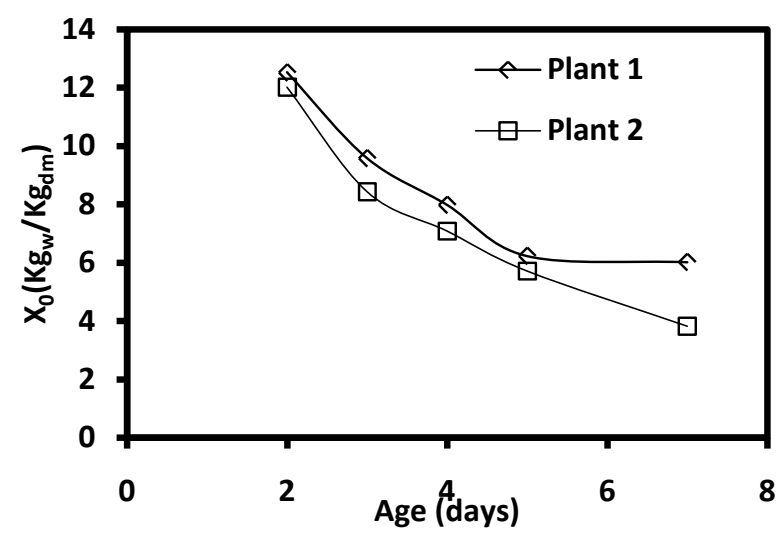

Figure 3. Okra initial water content evolution during its maturity.

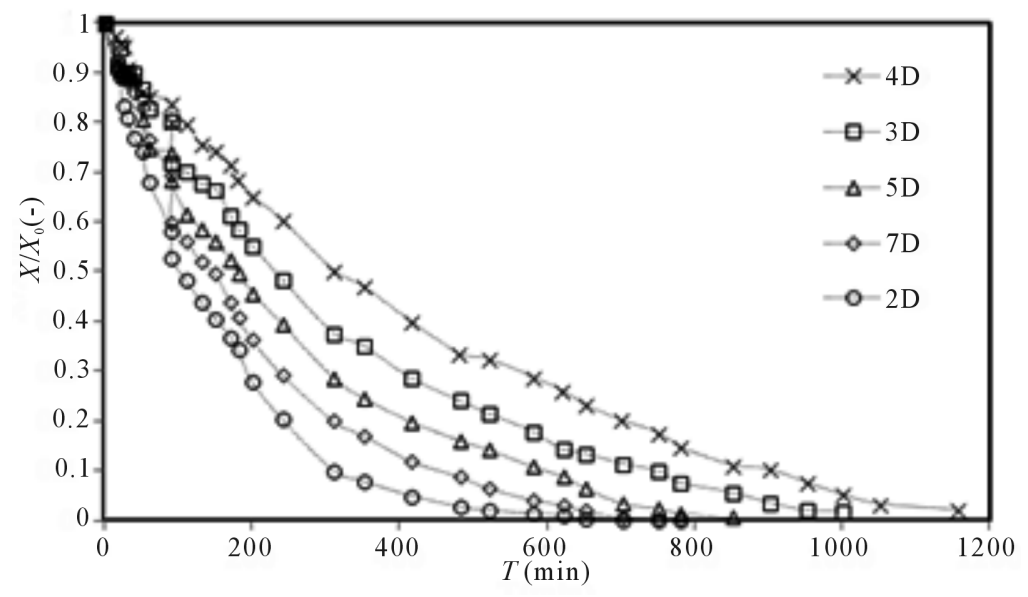

Figure 4. Influence of okra age on its drying curves (for 2, 3, 4, 5, 7 days old).

erning moisture movement in the samples. Similar results were obtained for green bean [15], for okra [16] for red chilli [17]. It is obvious from Figure 4 that okra age caused an important impact on its drying curves.

The time required to reduce the moisture ratio to any given level was dependent on the sample age. At 2, 3, 4, 5 and 7 days old, the drying effective time was respectively 780, 1000, 1155, 850 and $750 \mathrm{~min}$. One can divide okra maturity in two periods. The first one (the youngest age or raw fruits), goes from 2 days old to 4days old and the second period (older age or ripe fruit) goes from 4 days old to 7 days old. The results indicated that age is an important parameter governing moisture movement in the okra samples during its convective drying. The results showed that increasing the age of okra involved not inevitably increasing or a decreasing of the drying time. From these results, we can deduce that the moisture content of the okra decreases with its age. On the other hand, the okra dries faster when it is very young or very old. Initial water content is not the parameter that governed the drying process. The reason of such result can proceed from the structure of the product, which changes according to okra ages as we can see in Figure 2. This means that the moisture transport is also controlled by inherent internal factors of maturity.

\subsection{Diffusion Coefficient}

Figures 5_and 6 show the influence of okra age on its effective diffusion coefficient at $60^{\circ} \mathrm{C}$. It can be seen that $\ln (M R)$ is almost proportional to drying time. We found the equation of this proportionality as reported in Table 1. From the curves plotted from $\ln (M R)$ versus time, we draw first the equation of the straight-line from which we deduced $\ln \left(4 / \beta^{2}\right)$ then the slope $k$ values.

Also, the different constants that permitted $D_{\text {eff }}$ calculation are found and recorded in Table 1 . The determined 


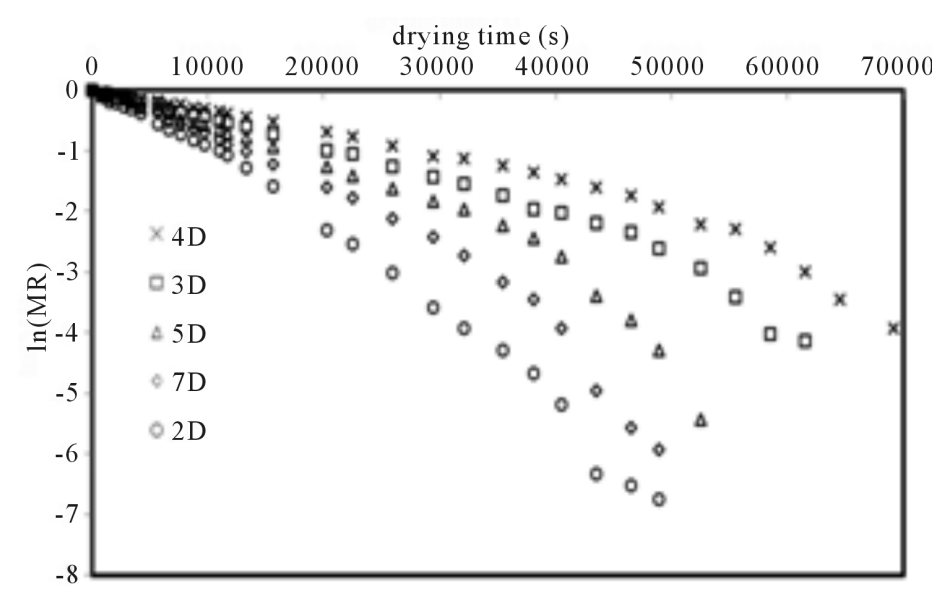

Figure 5. $\ln (M R)$ evolution versus okra age at $60^{\circ} \mathrm{C}$.

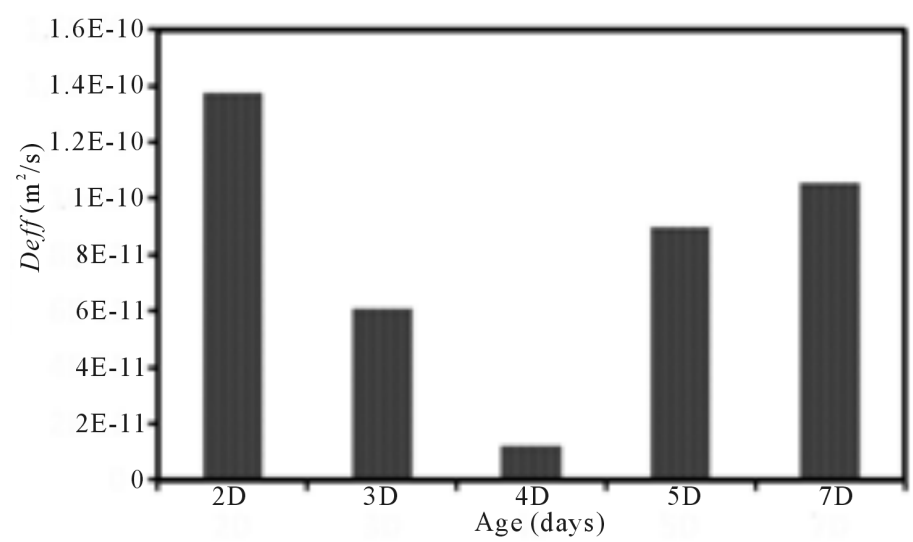

Figure 6. Okra effective diffusion coefficient evolution with okra age.

Table 1. Data draw from okra draying curve for $D_{\text {eff }}$ calculation.

\begin{tabular}{ccccccc}
\hline Age (days) & Equation & Radius $(\mathrm{m})$ & $\ln \left(\frac{4}{\boldsymbol{\beta}^{2}}\right)$ & $k$ & $\beta$ & $D_{\text {eff }}\left(\mathrm{m}^{2} / \mathrm{s}\right)$ \\
\hline 2 & $\mathrm{y}=-\mathbf{0 . 3 2 0 7 x + 0 . 0 0 0 1}$ & 0.0021 & 0.3207 & 03207 & 1.703 & $1.38 \mathrm{E}-10$ \\
3 & $\mathrm{y}=-\mathbf{0 . 3 0 3 3 x + 0 . 0 0 0 0 2}$ & 0.0030 & 0.3033 & 0.3033 & 1.718 & $6.09 \mathrm{E}-11$ \\
4 & $\mathrm{y}=-\mathbf{0 . 2 0 3 4 x + 0 . 0 0 0 0 1}$ & 0.0021 & 0.2034 & 0.2034 & 1.806 & $1.23 \mathrm{E}-11$ \\
5 & $\mathrm{y}=-\mathbf{0 . 1 3 9 5 x}+\mathbf{0 . 0 0 0 0 5}$ & 0.0025 & 0.1395 & 0.1395 & 1.865 & $8.98 \mathrm{E}-11$ \\
7 & $\mathrm{y}=-\mathbf{0 . 1 5 8 4 x}+\mathbf{0 . 0 0 0 0 9}$ & 0.0020 & 0.1584 & 0.1584 & 1.847 & $1.05 \mathrm{E}-10$ \\
\hline
\end{tabular}

values of $D_{\text {eff }}$ for different states of maturity are given in Figure 6. The effective diffusivities of okra were 1.38 $\times 10^{-10}, 6.09 \times 10^{-11}, 1.23 \times 10^{-11}, 8.98 \times 10^{-11}$, and $1.05 \times 10^{-10} \mathrm{~m}^{2} / \mathrm{s}$ respectively for $2,3,4,5$ and 7 days old. The values lie within the general range of $10^{-11} \mathrm{~m}^{2} / \mathrm{s}$ to $10^{-9} \mathrm{~m}^{2} / \mathrm{s}$ for food materials [18]. However, lower values were observed in this work than in the previous studies which might be due in part to varietal differences and also to method of sample preparation. Results showed (Figure 6) that okra age can be divided on two parts. For the first period, ( 2 - 4 days old) okra effective diffusion coefficient decrease with its age. At the second period (4 - 7 days old) okra effective diffusion coefficient increases when okra age increases. A minimum were reached at 4 days old in this study.

\section{Conclusions}

The influence of maturity of okra in the range of 2 - 7 days old at $60^{\circ} \mathrm{C}$ of drying air temperature for okra was 
studied.

The result allows predicting drying behavior of okra according to its age. Contrary to all expectations, okra drying time does not increase or decrease versus its age. It was found from the experimental results that okra maturity has important influence on its behavior during convective drying. At 2, 3, 4, 5 and 7 days old, the drying effective time was respectively 780, 1000, 1155, 850 and $750 \mathrm{~min}$. Effective diffusivities of the okra in this order of age were $1.38 \times 10^{-10}, 6.09 \times 10^{-11}, 1.23 \times 10^{-11}, 8.98 \times 10^{-11}$, and $1.05 \times 10^{-10} \mathrm{~m}^{2} / \mathrm{s}$. The youngest (two days old) and the oldest (seven days old) fruit dried fast, and the middle one (4 days old) retained more moisture. The reason that can explain this situation is to consider the consistence of the matter inside the product. In fact, the younger okras generally had high initial water content while the older okras decrease their initial water content. Whole okra at 2, 3, 4, 5 and 7 days old has respectively 12.27, 9.00, 7.53, 5.97 and $4.92 \mathrm{~K}_{\mathrm{gw}} / \mathrm{Kg}_{\mathrm{dm}}$ of initial water contain. The youngest fruit with high water content reveals soft and breakable. This physical characteristic makes transfers easy. The oldest one has low water content and high fibers content. It weakly withstands to transfers.

\section{References}

[1] Sankar, B., Abdul, J.C., Manivannan, P., Kishorekumar, A., Somasundaram, R. and Panneerselvam, R. (2008) Relative Efficacy of Water Use in Five Varieties of Abelmoschus esculentus (L.) Moench. under Water-Limited Conditions Colloids and Surfaces. Biointerfaces, 62, 125-129. http://dx.doi.org/10.1016/j.colsurfb.2007.09.025

[2] Avallonea, S., Tiemtorea, T.W.E., Rivierb, C. and Trècheb, S. (2008) Nutritional Value of Six Multi-Ingredient Sauces from Burkina Faso. Journal of Food Composition and Analysis, 21, 553-558. http://dx.doi.org/10.1016/j.jfca.2008.04.012

[3] Camciuc, M., Deplagne, M., Vilarem, G. and Gaset, A. (1998) Ocra (Abelmoschus esculentus L. Moench.) a Crop with Economic Potential for Set Aside Acreage in Frances Industrial. Crops and Products, 7, 257-264. http://dx.doi.org/10.1016/S0926-6690(97)00056-3

[4] Sengkhamparn, N., Sagis, L.M.C., Renko de Vries, A., Henk Schols, H.A., Sajjaanantakul, T., Alphons, G.J. and Voragen, A.G.J. (2008) Physicochemical Properties of Pectins from Ocra Abelmoschus esculentus L. Moench. Food Hydrocolloids, 24, 35-41. http://dx.doi.org/10.1016/j.foodhyd.2009.07.007

[5] Adelakun, O.E., Oyelade, O.J., Ade-Omowaye, B.I.O., Adeyemi, I.A. and Van de Venter, M. (2009) Chemical Composition and the Antioxidative Properties of Nigerian Ocra Seed (Abelmoschus esculentus Moench) Flour. Food and Chemical Toxicology, 47, 1123-1126. http://dx.doi.org/10.1016/j.fct.2009.01.036

[6] Ouoba, K.H., Desmorieux, H., Zougmoré, F. and Naon, B. (2010) Caractérisation du Séchage Convectif du Gombo, Influence de la Découpe et de ses Constituants. Afrique SCIENCE, 10, 37-48. http://www.afriquescience.info

[7] FAOSTAT (Food and Agricultural Organization of the United Nations) (2008) On-Line and Multilingual Database Currently Covering International Statistics. http://faostat.fao.org/site/339/default.aspx

[8] Kordylas, J.M. (1991) Processing and Preservation of Tropical and Subtropical Foods. Macmillan Education Ltd.

[9] Corzo, O., Bracho, N. and Alvarez, C. (2008) Water Effective Diffusion Coeffcient of Mango Slices at Different Maturity Stages during Air Drying. Journal of Food Engineering, 87, 479-484. http://dx.doi.org/10.1016/j.jfoodeng.2007.12.025

[10] AOAC (Association of official Chemists) (1990) Official Methods of Analysis. Washington AC, 934-06.

[11] Crank, J. (1975) The Mathematics of Diffusion. 2nd Edition, Oxford University Press, London, 69-88.

[12] Nuh, D.N. and Brinkworth, B.J. (1997) A Novel Thin-Layer Model for Crop Drying. Transactions of the American Society of Agricultural Engineers, 40, 659-669.

[13] Pala, M., Mahmutoglu, T. and Saygi, B. (1996) Effects of Pretreatments on Quality of Open-Air and Solar Dried Apricots. Nahrung/Food, 40, 137-141.

[14] Riva, M. and Peri, C. (1986) Kinetics of Sun and Air Drying of Different Varieties of Seedless Grapes. Journal of Food Technology, 21, 199-208. http://dx.doi.org/10.1111/j.1365-2621.1986.tb00441.x

[15] Roselló, C., Simal, S., SanJuan, N. and Mulet, A. (1997) Nonisotropic Mass Transfer Model for Green Bean Drying. Journal of Agriculture and Food Chemistry, 45, 337-342

[16] Gogus, F. and Maskan, M. (1999) Water Adsorption and Drying Characteristics of Okra (Hibiscus Esculentus L.). Drying Technology, 17, 883-894. http://dx.doi.org/10.1080/07373939908917576

[17] Gupta, P., Ahmed, J., Shivhare, U.S. and Raghavan, G.S.V. (2002) Drying Characteristics of Red Chilli. Drying Technology, 20, 1975-1987. http://dx.doi.org/10.1081/DRT-120015579

[18] Madamba, P.S., Driscoll, R.H. and Buckle, K.A. (1996) The Thin-Layer Drying Characteristic of Garlic Slices. Journal of Food Engineering, 29, 75-97. http://dx.doi.org/10.1016/0260-8774(95)00062-3 
O. K. Honoré et al.

\section{Nomenclature}

\begin{tabular}{cccc}
\hline \multicolumn{1}{c}{ Parameters } & \multicolumn{2}{c}{ Subscripts } \\
\hline \\
$k$ & diffusivity $\left(\mathrm{m}^{2} \cdot \mathrm{s}^{-1}\right)$ & 0 & initial, $\mathrm{t}=0 \mathrm{~s}$ \\
$m$ & slope, $\left(\mathrm{s}^{-1}\right)$ & $c$ & cylinder \\
$r$ & masse $(\mathrm{kg})$ & $d m$ & dry matter \\
$t$ & radius $(\mathrm{m})$ & $e f f$ & effective \\
$t$ & drying time, $(\mathrm{s})$ & $e q$ & equilibrium \\
$X$ & time $(\mathrm{s})$ & $f$ & final \\
$\beta$ & moisture content, $\left(\mathrm{kg}_{\mathrm{w}} \cdot \mathrm{kg}_{\mathrm{dm}}^{-1}\right)$ & $s$ & solid, \\
\hline
\end{tabular}

